Natalya Shelkova

\title{
INTRAHOUSEHOLD POWER IN RUSSIA AND THE MATERNAL CAPITAL LAW
}

It has been documented that the introduction of market economy institutions in Russia has disadvantaged Russian women, weakening their economic position and their power within the family. This paper investigates whether the introduction of the 2007 the Maternal Capital Law, which aims to promote fertility by granting Russian women a non-cash subsidy for having more than one child, affected the intrahousehold balance of power in Russian families. In order to investigate this hypothesis, the paper looks at changes in the ratio of family expenditure on children to spending on alcohol and tobacco before and after passing of the law. Data from the Russia Longitudinal Monitoring Survey (RLMS-HSE), 2002 to 2010, is used. The estimated regression models employ the difference-in-difference methodology and are based on Lundberg, Pollack and Wales, who researched a similar policy shift in the UK in 1970s. The results demonstrate that the year 2008 was a critical turning point: starting with 2008 the ratio of family expenditure on children to spending on alcohol and tobacco increased for families with two or more children (the results are statistically significant). After 2007, on average, expenditure on children increased by fifty-nine roubles per every ruble of alcohol and tobacco expenditures (mesearured in 2002 roubles), nearly doubling. The effect in families with a husband not holding a college degree was shown to be larger and more siginifcant than in families with collegeeducated husbands. It is concluded that the 2007 Law has had a positive impact on the bargaining power of Russian women.

Keywords: women power, family bargaining, transitional economies

DOI: 10.17323/727-0634-2018-16-2-371-386

Natalya Y. Shelkova- Ph.D., Associate Professor, Economics Department, Guilford College, Greensboro, USA. Email: shelkovany@guilford.edu 


\section{Introduction}

Russian women, praised by poets for their strength and beauty, have long held an unequal position in the Russian family and society. The Soviet government, which promoted equality at work and in education, did not achieve equality in the family life for Russian women. Women, historically well-educated and strongly attached to the labour force, have led familial lives that remained largely traditional. Society expected women to be good mothers and wives and have successful careers, and women strove to play both roles, striving for perfection in both areas. Most Soviet families had a strict division of labour, similar to traditional societies where women stayed at home. Married women carried out a disproportionately large share of the housework and childcare. Cooking, cleaning, shopping, making and repairing clothes for family members were on the shoulders of women.

Emancipation and feminist movements in the U.S. over the past half-century have empowered American women. The post-World War II American economy was strong and women started to enter the labour force, encouraged by the growth of women-friendly occupations (such as typists, telephone operators, flight attendants etc.). Equalizing educational opportunities, the Pill and the growth in household technology (Goldin 2006) have also made women's position in the American family stronger, manifesting itself in greater participation in family decisionmaking and sharing housework and childcare responsibilities with men.

However, the experiences of Russian women in the same period were quite different. Soviet society, in ruins after the war, lost a colossal number of primeage men, negatively affecting the ratios in the marriage market (Brainerd 2016). Though women who joined the labour force during the war continued to be employed, the increased competition in the marriage market tipped the family balance of power, making married women's share of family resources less equal than men's. Yet, as the demographic situation improved in the 1960s and new cohorts of men entered the marriage market, women's position in the family did not significantly change. Chronic shortages of consumer products coupled with low pay forced Soviet families to engage in significant domestic production. Married women were sewing, knitting, gardening, and making home preserves on an 'industrial' scale, not as a hobby, but as a necessary condition for survival. Substantial domestic production without much household technology required 'strong hands', and benefited immensely from the presence of men, as the market household services were poorly developed in the Soviet economy.

The collapse of the Soviet Union brought about many changes. The changing structure of the economy increased choices. New labour laws allowed them to choose whether to work, whereas before paid employment was nearly mandatory. The opening of borders made consumer goods, including household technology and western contraceptives, widely available. As abortion was not longer a major instrument for birth control, women gained greater flexibility in family planning and better health. The market economy not only brought an abundance 
of consumer goods, including the most up-to-date household appliances, but also led to the emergence of a variety of markets for services, which could replace men when it came to running the household. Women pursued higher education and career advancement in greater numbers.

While the trend towards more equal distribution of power in the Russian family was noticed since mid-2000s (see the literature review below), this paper takes a more specific event - the 2007 introduction of the Maternal Capital Law and the period surrounding it (2002-2010) that further promoted women's power. In 2006, concerned with a rapidly declining population, the Russian government passed several laws and regulations to stimulate fertility (Elizarov 2012). In 2007, several child subsdies were increased and new subsidies introduced: higher monthly subsidies for children under one and a half years (from 700 to $1,500-6,000$ roubles), new subsidies for non-working mothers of young children (1,500 roubles for the first child and 3,000 roubles for additional children) and payments for working mothers ( $40 \%$ of wages), as well as a new subsidy given to families who has a newborn child (7,000 to 10,000 roubles), and several other measures intended to improve medical care for expectant and new mothers. But the most significant and innovative change was the Maternal Capital Law policy passed at the end of 2006, which promised to award 250,000 roubles to mothers who give birth to a second or higher order child.

While there are many social science theories that analyze family power dynamics and the allocation of family resources, such as resource and cultural theories in sociology, as well as various theories in anthropology and demography, this paper adopts a pure economics approach to the topic, with family bargaining theory serving as a basis for the theoretical model and discussion. The hypothesis examined in the paper is whether the introduction of the Maternal Capital Law has further tilted the balance of power in Russian family to favour women. To investigate this hyposesis the paper uses data from the Russia Longitudinal Monitoring Survey (RLMS-HSE).

The paper structured as follows. The next section reviews literature on intrafamily allocation that uses Russian data. The following section discusses theoretical bargaining models and their estimation. After formulating an empirical model and describing the data, the paper proceeds to regression analysis, examining changes in the ratio of family expenditure on children to spending on alcohol and tobacco. The findings and a brief conclusion are presented at the end of the paper.

\section{Related Literature}

The question of the relative positions of women and men in post-Soviet Russia has been the focus of several previous studies. Economic shocks, including the economic transition that followed the collapse of the Soviet Union and the financial crisis of 1998, were shown to disproportionately affect 
women. In the mid-2000s women's economic positions improved due to economic recovery and institutional changes that had finally taken root.

Brainerd (1998) showed that in the early 1990s Russian women were significantly disadvantaged, as women's wages declined more sharply relative to men. Selezneva (2010) looked both at wages and family distribution of labour, examining data on pay, income sharing, housework and childcare. She found a mismatch between the roles carried out by women at home and at work: the socially imposed role of the traditional housewife was matched nearly equal demands of being a breadwinner. Even with the rise of their wages in 19941998 the share of domestic duties carried out by women did not decrease, contributing to their rising unhappiness with marriage. However, Selezneva recorded a shift towards a more equal distribution of work within the family in 2000-2004, a sign of women's 'emancipation'.

Lacroix and Radtchenko (2011) examined labour supply of Russian men and women, and concluded that the position of women worsened in the aftermath of the 1998 financial crisis. The estimated income elasticities revealed that an increase in the husband's wage increased the share of family resources controlled by the husband, but did not benefit the wife, while an increase in the wife's wage benefited the husband.

Kalugina, Sofer and Radtchenko (2009) used the subjective response data from RLMS-HSE to study families' income sharing, utility and inequality as a function of relative wages and age difference between spouses. They found that the higher the wife-to-husband wage ratio, the higher subjective utility. They also found that, starting with 2000-2003, resources in Russian families began to be shared more equally.

\section{Bargaining and Distribution in the Family}

Economists have long acknowledged that the family is not a collection of individuals who act in unison, maximizing the family's utility by pooling and allocating family resources according to a common preference. The common preference or unitary models of family behavior, prevalent till about the 1980s, were questioned by Manser and Brown (1980) and McElroy and Horney (1981), who proposed to model the family's dynamics as a bargaining game (see Lundberg, Pollak, 1996, for a survey). The alternative 'collective' models of the household, assume that family members have different preferences with regards to how family resources are allocated; through a process of bargaining they reconcile their preferences and arrive at a joint decision (see surveyes by Alderman et al. 1995; Browning et al. 2004).

The bargaining models assume that the strength of spouses in a bargaining game depends on a number of distributional factors. These factors are generally external to the family, such as spouse's wage contribution to the family budget, non-wage income, resources brought to the family at marriage (such as dowries), 
marriage opportunities reflected in gender ratios in marriage markets, the quality of available mates, and overall family and marriage institutions (divorce and domestic violence laws, religious customs and traditions, etc).

Bargaining between (Russian) spouses can be modelled using the following collective model (Chiappori, Fortin, Lacroix, 2002; see also Chiappori 1992). Spouses, indexed by $i(=1,2)$ have egotistical preferences and maximize utility:

$$
\begin{gathered}
\max U^{i}\left(1-h^{i} ; C^{i} ; z\right) \\
h^{i}, C^{i} \\
\text { subject to } w_{i} h^{i}+\varphi^{i} \geq C^{i},
\end{gathered}
$$

where $0 \leq h^{i} \leq 1$ is the individual labour supply, $C^{i}$ is the vector of private consumption goods, $w^{i}$ is the wage rate, and $z$ is the vector of preference factors (age, education, etc.). Function $\phi=\left(w_{1}, w_{2}, y, z, s\right)$ is the sharing rule, which determines how non-labour income $y$ is shared between spouses depending on wages, preferences; $s$ is the vector of external distributional factors discussed above.

Assuming that utility function is quasi-concave, increasing, and continuously differentiable, the solution to the utility maximization problem will produce estimable labour supply and demand-for-consumption-goods functions for each spouse:

$$
\begin{aligned}
& h^{i}=f\left(w_{i},\left(w_{1}, w_{2}, y, s, z\right), z\right) ; \\
& C^{i}=f\left(w_{i},\left(w_{1}, w_{2}, y, s, z\right), z\right) .
\end{aligned}
$$

Evaluating the bargaining strength of women customarily involves an estimation of demand functions for goods and children outcomes. Such indicators as fertility, various child health and developmental measures, as well as resources devoted to children are analyzed, as children are assumed to be 'goods' of greater importance to women rather than men. Children in families in which women have a stronger position and are shown to have better nutrition, health, education (Lundberg et al. 1997; Thomas 1990; Haddad, Hoddinott 1994; Maitra 2004). To evaluate spouses' relative strength, authors have looked, among other things, at private spending on men's and women's clothing (Browning et al. 1994) and resource allocation upon divorce (Chiappori et al. 2002).

Empirically such investigations entail identifying a link between a change in external factors that affect spousal bargaining power (i.e. a change in the distributional factors), and a change in the observed family's outcomes: consumption and labour market choices, family size, nutrition, health, etc. Authors have used different proxies for distributional factors (see survey by Quisumbing, Maluccio 2000). These include spousal assets (Doss 1996; Thomas et al. 1999), unearned income (Schultz 1990; Thomas 1990), transfer payments and welfare receipts (Lundberg et al. 1997; Rubaclava, Thomas 2000). When it comes to the allocation outcomes, authors have used expenditure on various categories of household goods, such as food, children clothing, services and 
alcohol (Attanasio, Lechene 2002); the wife's labour supply - hours and participation rate (Blundell et al. 2007); fertility, nutrient intakes, child survival and child anthropometrics (Thomas 1990).

\section{Data and Empirical Model}

To investigate how the balance of power changed in the Russian families in 2000s and whether the Maternal Capital Law affected such a balance, this paper adapts the empirical model of Lundberg et al. (1997). The researchers tested a pooling hypothesis of family allocation using the data from the child subsidy program in the UK in the late 1970s, when the mechanism of allocating child subsidies was changed. The subsidy payment no longer was a general tax break (usually appearing in the husband's pay check), but rather became a direct payment to the wife.

Somewhat similarly, in 2007, in an effort to reverse Russia's declining birth rates, the Russian government passed the Maternal Capital Law. The law awards a non-cash grant equivalent to $\$ 11,000$ (indexed annually) to a mother who gave birth to the second or higher-order child (see Slonimczyk and Yurko (2013), for a detailed explanation of the program and discussion of concurrent events and policies). As soon as the child turns three, families can use the grant for strictly defined causes, such as an improvement to the family home, paying for the child's education, or investments in the mother's pension account. The subsidy money cannot be cashed.

According to the family bargaining theories, both the change in the UK's child subsidy policy and the introduction of the Maternal Capital Law in Russia should have increased women's bargaining power. As the literature suggests, the effects of such an increase would translate into higher marriage rates, declining age differences between spouses, increased fertility rates, and particularly, increased labour force participation. It would also change the way family resources are allocated: as women control a greater share of resources, they would spend more on children, particularly on food and clothing.

Empirically et al. (1997) investigated the change in bargaining by looking at the link between the ratio of family spending on female to male clothing (on the one side) and family composition: the number of children and their age (on the other side), before and after the shift in child subsidy policy. Similarly, we look at the ratio of family expenditures on children to expenditures on alcohol and tobacco on the one side and family composition on the other, throughout 2000s and around the passage of the Maternal Capital Law.

\section{Data}

The paper uses 2002-2010 data from the Russia's Longitudinal Monitoring Survey (RLMS-HSE), a series of nationally representative surveys that monitor 'the effects of Russian reforms on the health and economic welfare of house- 
holds and individuals in the Russian Federation.' ${ }^{1}$ The survey began in 1992 and is a detailed study of Russian adults, children, and communities. It is highly representative of the population's composition by gender, education, geographic location and urbanization level.

Table 1 .

Sample Description

\begin{tabular}{|c|c|c|c|c|c|c|}
\hline & $\widetilde{\Xi}$ & $\underset{⿱}{\grave{2}}$ & 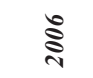 & $\stackrel{\infty}{\sim}$ & $\stackrel{\overbrace{}}{2}$ & 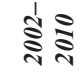 \\
\hline Sample size & 1051 & 1033 & 1141 & 1015 & 1578 & 10096 \\
\hline One-child families & $65.7 \%$ & $65.4 \%$ & $68.7 \%$ & $67.1 \%$ & $63.2 \%$ & $66.6 \%$ \\
\hline Two-child families & $28.3 \%$ & $29.7 \%$ & $26.8 \%$ & $24.1 \%$ & $30.8 \%$ & $28.3 \%$ \\
\hline Three-or-more-child families & $6.0 \%$ & $4.8 \%$ & $4.5 \%$ & $3.8 \%$ & $6.0 \%$ & $5.0 \%$ \\
\hline Children under 3 y.o. & $20.8 \%$ & $20.3 \%$ & $22.0 \%$ & $22.8 \%$ & $27.2 \%$ & $22.7 \%$ \\
\hline Children 3-7 y.o. & $25.0 \%$ & $28.3 \%$ & $28.7 \%$ & $32.8 \%$ & $32.8 \%$ & $29.9 \%$ \\
\hline Children $7-18$ y.o. & $71.0 \%$ & $69.7 \%$ & $65.9 \%$ & $64.4 \%$ & $65.6 \%$ & $66.8 \%$ \\
\hline Husband with college diploma & $19.5 \%$ & $19.3 \%$ & $19.5 \%$ & $20.6 \%$ & $24.7 \%$ & $20.7 \%$ \\
\hline Wife with college diploma & $21.3 \%$ & $22.4 \%$ & $27.0 \%$ & $28.6 \%$ & $34.0 \%$ & $27.1 \%$ \\
\hline Real hh income (in 2002 roubles) & 7,547 & 9,014 & 11,220 & 13,527 & 13,361 & 11,136 \\
\hline Real expenditures on children per week & 140.5 & 149.3 & 178.7 & 218.2 & 236.6 & 183.3 \\
\hline Real expenditures on alcohol and tob. & 79.47 & 79.77 & 81.85 & 82.11 & 82.38 & 81.77 \\
\hline Treatment group & $9.6 \%$ & $15.4 \%$ & $18.5 \%$ & $24.7 \%$ & $32.2 \%$ & $20.3 \%$ \\
\hline Ratio of child/alcohol expenditures & 39.70 & 50.09 & 80.12 & 130.83 & 180.97 & 94.41 \\
\hline (st.dev.) & $(112.8)$ & $(129.8)$ & $(215.3)$ & $(352.7)$ & $(410.7)$ & $(268.7)$ \\
\hline \multicolumn{7}{|l|}{ Household characteristics } \\
\hline Age of husband & 37.03 & 36.6 & 36.8 & 36.2 & 36.6 & 36.6 \\
\hline Age of wife & 35.13 & 34.6 & 34.52 & 34.2 & 34.4 & 34.5 \\
\hline Number of children & 0.74 & 1.65 & 1.60 & 1.58 & 1.66 & 1.43 \\
\hline Husband works? & $85.2 \%$ & $86.0 \%$ & $88.3 \%$ & $89.3 \%$ & $89.7 \%$ & $87.5 \%$ \\
\hline Wife works? & $75.5 \%$ & $76.7 \%$ & $76.7 \%$ & $80.1 \%$ & $78.6 \%$ & $77.5 \%$ \\
\hline $\begin{array}{l}\text { Report positive children expenditures } \\
\text { (last three months) }\end{array}$ & $86.1 \%$ & $88.3 \%$ & $90.6 \%$ & $90.6 \%$ & $91.4 \%$ & $88.9 \%$ \\
\hline Report alcohol and tobacco expenditures & $74.3 \%$ & $73.6 \%$ & $70.5 \%$ & $70.9 \%$ & $66.7 \%$ & $71.3 \%$ \\
\hline
\end{tabular}

${ }^{1}$ Russia Longitudinal Monitoring survey, 'RLMS-HSE', conducted by the National Research University Higher School of Economics and 'Demoscope' together with the Carolina Population Center, University of North Carolina at Chapel Hill and the Institute of Sociology RAS (http:// www.cpc.unc.edu/projects/rlms-hse). 
The choice to focus on 2002-2010 data was driven by several considerations. First, Russia's economic conditions stabilized in 2000s, resulting in better quality, more consistent data. Second, the review of prior studies pointed out that the mid-2000s could have been a turning point for a qualitative change in intrahousehold power dynamics. And finally, the passage on the Maternal Capital Law also falls within this period.

The data panel consisted of matched records of couples with children from the adult survey of the RLMS-HSE merged with household data, with each family present in the set for at least two rounds. The set was also restricted to: families wives aged between 16 and 55 and husbands aged between 16 and 60; families headed by a non-retired person living without grandparents; and report non-zero income. Both employed and stay-at-home spouses were included in the sample. Income and expenditure variables were adjusted for inflation using the appropriate price indces published by the Russia's federal statistical agency. Income outliers, defined as the top and the bottom $1 \%$ of the income distribution, and alcohol and tobacco spending outliers, defined as families that spend more than 2,000 Russian roubles per week (in 2002 roubles), were excluded. Small numbers of children-expenditure outliers were also excluded, defined as families that spent more than 100,000 Russian roubles per month. Table 1 presents descriptive statistics.

\section{Regression Models}

Two regression models were estimated based on the model by Lundberg et al. (1997). The first model examined the overall trends in bargaining power. The second model attempts to discern the impact of the Maternal Capital Law on the bargaining power using a more narrow difference-in-difference approach.

The first model's equation is:

$$
\begin{aligned}
& \text { Ratio }_{j t}=\alpha_{0}+\alpha_{1} \text { ChildAgejt }+\alpha_{2} \text { NumChild }_{j t}+\alpha_{3} X_{j t}+\alpha_{4} \text { Year }_{j t}+ \\
& +\beta\left(\text { NumChild }_{j t} x \text { Year }_{j t}\right)+u_{j t}+\varepsilon_{j t}
\end{aligned}
$$

with the coefficient of interest $\beta$.

The second model's equation is:

$$
\begin{aligned}
& \text { Ratio }_{j t}=\gamma_{0}+\gamma_{1} \text { ChildAge }_{j t}+\gamma_{2} \text { NumChild }_{j t}+\gamma_{3} X_{j t}+\gamma_{4}(\text { Post2007) })_{j t}+ \\
& +\gamma_{5}(\text { T reatment })_{j t}+\theta\left(\text { Treatment } j \text { } X \text { Post } 2007_{j t}\right)+v_{j}+\omega_{j t}{ }^{\text {? }}
\end{aligned}
$$

with the coeffcient of interest $\theta$. In the above equations, the dependent variable Ratio $_{j t}$ is a ratio of current real expenditures on children, which includes expenditure on children's clothing, education and extra-curricular activities, to family expenditures on alcohol and tobacco, which includes expenditure on vodka, wine, beer, and tobacco products. Expenditure on alcohol and tobacco are deflated by 
the offcial Russia's consumer price index on food items, while children's expenditure are deflated by the price index on non-food items. In order to utilize information from zero-alcohol-expenditure families, we replace such zero expenditure by 1 (to avoid the problem of division by zero and preserving valuable data).

The ChildAge ${ }_{j t}$ is the vector of dummy variables indicating whether a family has: children younger than 3 years old, children of preschool age (3 to 7 y.o.), or children of school age (7 to 18 y.o.). The variable NumChild ${ }_{i t}$ is the vector of three dummy variables that indicate the number of children in a family: one-child families (reference category), two-child families, and families with three or more children.

The vector $X_{j t}$ of variables includes the natural logarithm of real household income, geographic location (urban vs rural), geographic region (Moscow/St. Petersburg - reference group, Northwest, Central, Volga region, Caucases, Urals, Western Siberia and Eastern Siberia), and the wife's college education. The last variable is included to control for changes in family power dynamics that could be changing throughout the period (independently from the effects of the Maternal Capital Law).

The year dummies Year $_{j t}$ are included in the first model to control for general year effects. The set of interaction dummies (NumChild X Year) ${ }_{j t}$, is used to track changes in family consumption behavior throughout the years. Its value is found by multiplying a year dummy by each of the three dummies describing family size. The hypothesis is that controlling for family income and composition, a change in the coeffcients on the interaction dummies would signal a change in the family bargaining regime.

In the second regression model we define a group of women who to be most likely affected by the law. Since the law provides the transfer to women who give birth, we use women of child-bearing age who have more than one child as the 'treatment group'. This group of women is forty years old or younger in the final round of data used and thirty-two or younger in 2002, and have two or more children (captured by the variable Treatment $t_{j t}$. The dummy variable Post $2007_{j t}$ indicates the time period after which the Maternal Capital Law entered into effect.

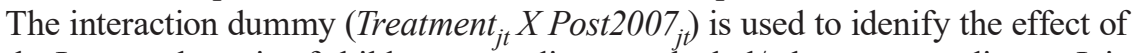
the Law on the ratio of children expenditure to alcohol/tobacco expenditures. It is hypothesized that, controlling for family income, family composition, age of children, and year effects, a change in the coeffcient on the interaction dummy would signal a change in the bargaining regime within the family due to the Law.

All regressions included the random effects term $u_{j t}$ and the error term $\varepsilon_{j t}$, with usual assumptions held.

\section{Results and Discussion}

Estimation results are presented in Tables 2 and 3 (both are random-effects unbalanced panel regressions weighted by the household weights). For 
multiple-category binary variables, the following categories were excluded as reference groups: one-child families, interaction dummies for 2002, the Moscow/St.Petersburg region, and year-number-of-children interactions for onechild families. Three versions of each model were estimated, using the entire sample of data and two subsamples: one for families where a husband does not have a college education (approximately $20 \%$ of the sample) and another for families with a college-educated husband. This division of the sample into two sub-samples was motivated by potential differences in family culture and power dynamics between the two types of families, with families where a husband does not have a college degree having a more traditional culture or lower income, and as a result, are potentially more affected by the new law.

Table 2.

Model 1 Estimation Results

\begin{tabular}{|c|c|c|c|c|c|c|}
\hline & & & \multicolumn{2}{|c|}{$\begin{array}{c}\text { Husband: } \\
\text { no college edu }\end{array}$} & \multicolumn{2}{|c|}{$\begin{array}{l}\text { Husband: } \\
\text { college edu }\end{array}$} \\
\hline & $\frac{5}{3}$ & 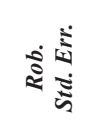 & š & ¿ & 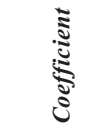 & 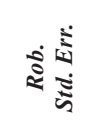 \\
\hline Child_under_3 & $-36.510 * *$ & $(13.905)$ & $-41.887 * *$ & (14.959) & -29.713 & $(33.436)$ \\
\hline Child_3_7 & $-30.976^{*}$ & $(15.023)$ & $-37.901^{*}$ & $(16.549)$ & -15.618 & $(34.042)$ \\
\hline Child_7_18 & 12.666 & $(15.006)$ & 5.692 & $(16.367)$ & 34.734 & $(35.081)$ \\
\hline Two_child & 16.008 & $(12.040)$ & 14.842 & $(12.251)$ & 47.954 & $(32.888)$ \\
\hline Three\&more_children & $46.427^{\dagger}$ & $(25.444)$ & $44.913^{\dagger}$ & $(27.069)$ & 55.980 & $(54.928)$ \\
\hline Log_real income & $21.627 * *$ & $(4.757)$ & $17.716^{* *}$ & $(4.758)$ & $20.764^{\dagger}$ & (12.139) \\
\hline Urban & -18.806 & $(9.516)$ & $-16.496^{*}$ & $(8.023)$ & -38.506 & $(30.715)$ \\
\hline Wife_college & $36.604 * *$ & $(8.254)$ & $25.074 * *$ & $(10.527)$ & 17.407 & $(16.282)$ \\
\hline Two_2003 & 1.793 & $(11.596)$ & 8.462 & $(12.790)$ & -37.401 & (28.753) \\
\hline Two_2004 & -8.764 & $(13.301)$ & 3.573 & $(14.348)$ & -51.113 & $(31.265)$ \\
\hline Two_2005 & 15.185 & $(14.660)$ & 18.701 & $(15.701)$ & 8.009 & $(36.201)$ \\
\hline Two_2006 & 28.244 & $(17.659)$ & $37.071^{*}$ & (18.935) & -24.991 & (48.993) \\
\hline Two_2007 & 29.129 & $(18.761)$ & 35.360 & $(21.670)$ & -11.916 & $(39.860)$ \\
\hline Two_2008 & $84.819^{* *}$ & $(30.617)$ & $102.260 * *$ & $(33.757)$ & 0.613 & (71.792) \\
\hline Two_2009 & $64.067 *$ & $(26.202)$ & $74.808^{*}$ & $(30.212)$ & -0.491 & $(53.485)$ \\
\hline Two_2010 & $114.449^{* *}$ & $(26.569)$ & $102.212^{* *}$ & $(29.516)$ & $127.853^{*}$ & $(60.787)$ \\
\hline Three\&more_2003 & 29.498 & $(25.662)$ & 29.149 & $(29.667)$ & 32.673 & $(40.346)$ \\
\hline Three\&more 2004 & 4.937 & $(27.369)$ & 2.772 & $(29.847)$ & 26.397 & $(70.627)$ \\
\hline
\end{tabular}




\begin{tabular}{|c|c|c|c|c|c|c|}
\hline & & & $\begin{array}{r}\text { Hus } \\
\text { no col }\end{array}$ & $\begin{array}{l}\text { and: } \\
\text { ge edu }\end{array}$ & & $\begin{array}{l}\text { and: } \\
\text { e edu }\end{array}$ \\
\hline & : & 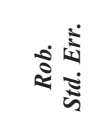 & : & ¿ & : & 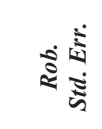 \\
\hline Three\&more_2005 & $123.070 *$ & (63.312) & 64.795 & $(47.294)$ & 378.441 & $(264.864)$ \\
\hline Three\&more_2006 & -2.074 & $(37.088)$ & 17.879 & $(40.025)$ & -108.770 & (86.014) \\
\hline Three\&more_2007 & 34.697 & (55.994) & 53.840 & $(60.955)$ & $-105.022^{\dagger}$ & $(57.129)$ \\
\hline Three\&more_2008 & $169.400^{\dagger}$ & $(102.685)$ & $191.024^{\dagger}$ & $(115.497)$ & 93.073 & $(145.246)$ \\
\hline Three\&more_2009 & $299.237 *$ & $(136.520)$ & $247.797^{\dagger}$ & (144.767) & 542.157 & $(370.045)$ \\
\hline Three\&more_2010 & 87.652 & $(64.752)$ & 70.925 & $(68.777)$ & 212.239 & (164.414) \\
\hline Year2003 & 3.459 & $(4.788)$ & -0.238 & $(5.340)$ & 14.212 & (11.319) \\
\hline Year2004 & $13.413 * *$ & $(5.346)$ & 7.104 & $(5.820)$ & $35.834 * *$ & (13.977) \\
\hline Year2005 & $17.575^{* *}$ & $(6.090)$ & 9.840 & $(6.431)$ & $51.120 * *$ & $(15.414)$ \\
\hline Year2006 & $30.929 * *$ & $(7.545)$ & 19.128 & $(7.215)$ & $90.439 * *$ & $(26.103)$ \\
\hline Year2007 & $38.037 * *$ & $(8.696)$ & $31.062^{* *}$ & $(9.356)$ & $71.738 * *$ & $(21.215)$ \\
\hline Year2008 & $59.796 * *$ & (11.508) & $41.440^{* *}$ & $(10.051)$ & $140.536^{* *}$ & $(39.318)$ \\
\hline Year2009 & $71.725^{* *}$ & $(10.240)$ & $63.223^{* *}$ & $(11.286)$ & $107.297 * *$ & $(24.191)$ \\
\hline Year2010 & $102.739 * *$ & (11.375) & $85.141^{* *}$ & (12.008) & $165.291^{* *}$ & $(28.373)$ \\
\hline Northwest & $71.820 * *$ & $(21.635)$ & $68.315^{* *}$ & $(22.606)$ & $142.496^{*}$ & $(72.826)$ \\
\hline Central & $33.960 *$ & (13.698) & $32.309^{*}$ & $(14.872)$ & 45.519 & $(30.067)$ \\
\hline Volga & 37.559 & (13.535) & $39.856^{* *}$ & (14.984) & 37.147 & $(28.458)$ \\
\hline Caucuses & $32.698 *$ & $(16.392)$ & 9.906 & $(16.447)$ & $109.505^{* *}$ & $(41.126)$ \\
\hline Ural & 1.467 & $(13.239)$ & 1.524 & $(13.838)$ & 14.836 & $(33.241)$ \\
\hline West_Siberia & -3.463 & (13.854) & -1.543 & $(14.743)$ & -5.854 & $(33.239)$ \\
\hline East_Siberia & 13.278 & (15.498) & 9.604 & $(16.296)$ & 32.432 & $(36.932)$ \\
\hline Constant & $-165.696^{*}$ & $(45.053)$ & $119.335^{* *}$ & $(45.562)$ & -183.649 & $(116.388)$ \\
\hline Avg. ratio (st.dev.) & 94.409 & $(268.685)$ & 82.397 & $(251.882)$ & 140.479 & $(321.104)$ \\
\hline \multicolumn{7}{|l|}{ Real child } \\
\hline spending & 183.291 & (214.513) & 173.932 & $(201.517)$ & 219.186 & $(255.254)$ \\
\hline Real alc.tob.spending & 81.771 & $(115.606)$ & 81.863 & (109.629) & 81.418 & $(136.146)$ \\
\hline
\end{tabular}

${ }^{* *}$ Significant at $1 \%$ level; ${ }^{*}$ Significant at $5 \%$ level; ${ }^{\dagger}$ Significant at $10 \%$ level

The results of both models and descriptive statistics indicate that throughout the 2000's Russian families increased their spending on children. In 2002 the av- 
erage weekly spending on children in our sample was 140 roubles and by 2010 it reached 237 roubles (in 2002 roubles). While real spending on alcohol and tobacco had also increased, it was not as dramatic, with real weekly spending on alcohol and tobacco in 2002 at seventy-nine roubles and in 2010 - eighty-two roubles.

Regression model 1 demonstartes that the ratio of children spending to alcohol and tobacco expenditure went up during 2002-2010, controlling for the number and age of children, household income, prices (embedded in the real income variable), the wife's college education and geographic location, reflective of the shift in family preferences in general, regardless of the effect of the Maternal Capital Law. The growth in coefficients on the year dummies is gradual and monotonic (for the full sample and the subsample of families where husband does not hold a college degree). The coefficients on the Post2007 dummy in the second model are also positive and statistically significant, reflecting the growth in the ratio after 2007.

For both models having college-educated husbands affects the ratio positively, perhaps due to preferences (alcohol and tobacco expenditure in both groups of families is nearly identical, Table 2). Having a college-educated wife also increases the ratio of children to alcohol/tobacco expenditure - as disccussed in the empirical bargaining literature, empowered women spend more on children. Interestingly but predictably, the marginal effect of the wife's college education is larger (and statistically significant) in families where the husband does not hold a college degree.

Both models also indicate that household income, having more children, and having school-age children ( 7 to 18 years of age) positively affect the ratio of children to alcohol and tobacco expenditure. Interestingly, families with similar characteristics (income, number of children, etc.) who live in rural locations demonstrate a higher expenditure ratio than their urban counterparts. Also, geographic location dummies tell us that families who live in European parts of Russia and Urals versus Eastern and Western Siberia have a larger ratio of children to alcohol and tobacco spending.

When it comes to the causal relationship between the Maternal Capital Law and women's power, the results of the first model demonstrate that 2008 was an important turning point: starting with 2008 the effect of family size in the form of interaction dummies on the ratio in question increases significantly for families with two or more children. Splitting the sample by husband's education allows a deeper insight. According to model 1 results, the Maternal Capital Law has made a larger and more significant impact on families where husbands do not have college education: the marginal improvement in the position of women in such families was larger especially in the first two years after the passing of the Law, in line with the basic principle of diminishing marginal returns.

Similarly, the results of the second model, a smaller more focused difference-in-difference regression with specifically defined treatment group of women (Table 3), also confirm that the Maternal Capital Law has changed intra-fami- 
ly allocations. In families with child-bearing-age wives who have more than one child, the investigated ratio rises after 2007 by 59.3 roubles of additional childrenrelated expenditure per ruble of alcohol/tobacco expenditures (joint sample), a significant hike given that the average ratio before 2007 was 56.1. If the ratio of women-borne expenditure (e.g. spending on children) to men-borne expenditure (e.g. alcohol and tobacco), as well as the choice of treatment group, adequately reflects women's respective bargaining power, then we can conclude that the 2007 Law had a positive impact on the bargaining power of Russian women.

Table 3.

Model 2 Estimation Results

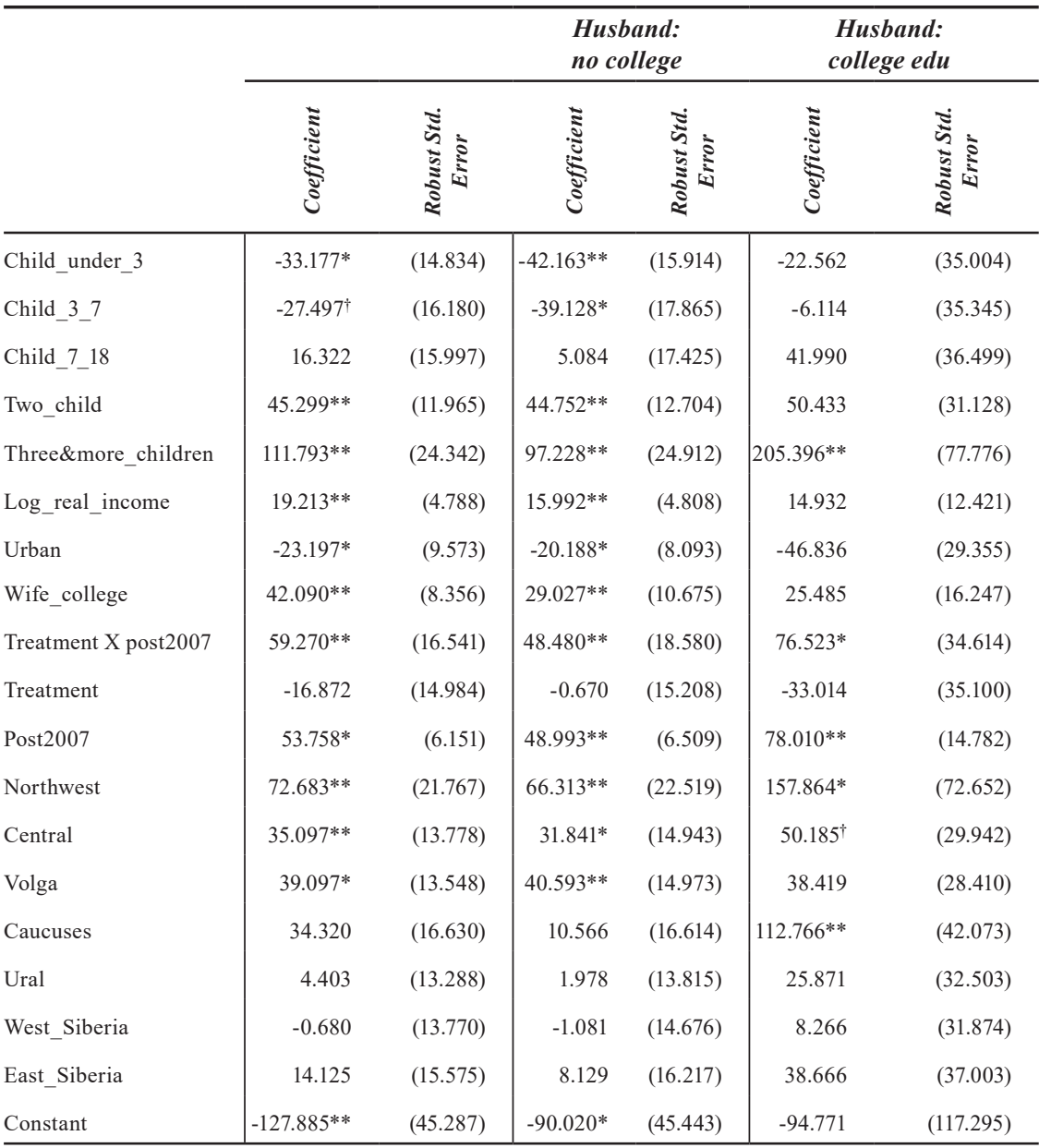

${ }^{* *}$ Significant at $1 \%$ level; ${ }^{*}$ Significant at $5 \%$ level; ${ }^{\dagger}$ Significant at $10 \%$ level 
While our results confirm that the bargaining balance of families in Russia changed throughout the 2000s, benefiting women and children as reflected in the shifts of family consumption patterns, several issues (or possible directions for future research) should be acknowledged.

As was mentioned in the introduction, in 2007-2008 the Russian government instituted several other smaller meausures intended to support expectant and new mothers, which could potentially complicate the interpretation of regression results. However, the argument can be made that while these measures were important, the size of the Maternal Capital and its novelty were more of a 'shock' to the system of intra-family power. Also, most of the other measures targeted child birth and support of mothers in general (starting with the first child), while the Maternal Capital was tied to the birth of the second or higherorder child. The model results indicate that relative to the one-child families it is the families with two or more children who were positively affected after 2007, supporting the claim of a causal effect of the Law on intra-family allocation.

Another question that could arise is how closely the children-to-alcohol consumption ratio reflects the bargaining strengths of spouses? To people familiar with Russian society and family life, the trend for increasing expenditure on children is rather obvious (we try to capture this trend with the year dummies and the real income variable). Is it possible that this trend reflects the effect of other external sources that are not related to the power position of spouses? Similarly, how valid is the alcohol and tobacco expenditure indicator for studying the bargaining strength of men? One can argue that the two are inferior goods, and the increase in the real incomes of Russians that took place in the 2000s might have negatively affected the expenditure on these goods. Therefore, it is advised to estimate the models with alternative proxies for men's bargaining strength, which are normal goods (for example, men's clothing, technology and sporting goods). However, it is also possible (and anecdotal evidence exists) that with the growth of income Russian consumers switch from cheap to increasingly more expensive alcohol and tobacco products.

And lastly, nearly every study of intrahousehold allocation and bargaining acknowledges the presence of endogeneity, which could be an issue in this study as well. Since one of the main determinants of bargaining power is spousal wages and income, the family's allocation outcomes are derived from these primary variables. We try to avoid this problem, first, by excluding wages (but not income) and other endogenous power-determining variables from the set of covariates, and, second, by assuming that changes in the consumption patterns experienced by families, namely due to the Maternal Capital Law, are exogenous to family allocation (while controlling for the overall income change).

\section{Conclusion}

The conducted study was an attempt to track changes in the intrahousehold allocation of resources and power in Russian families with a special emphasis 
on the mid-2000s, continuing the series of studies of Russian women that examine women's well-being throughout the 1990s and early 2000s. The change in the relative bargaining strength of women has been 'primed' by women in the 1990s, when their economic positions were weaker relative to men and their futures uncertain. Today's generation of Russian women invest more in higher education, move into professional and service sector jobs, marry later in life, enjoying, as a result, greater incomes and more equatable positions in the Russian family. The 2007 Maternal Capital Law, while promoting fertility and familial life, has further contributed to this increase in women's power. The paper identified a statistically significant increase in the ratio of children to alcohol/ tobacco expenditure following the passage of the 2007 Maternal Capital Law. The estimated models (based on Lundberg et al. 1997) provided evidence of such a change in intra-family allocations.

Several directions for future research can be pointed out. Firstly, it would be interesting to examine how changes that the Law brought about for women affected Russian men. If men continue to expect women to fullfill traditional family roles, stronger women might not be able or willing to meet such expectations, which are already manifested in increasing rates of divorce (or indeed in acknowledgement by the government of the need to exogenously stimulate fertility). Thus, the Maternal Capital Law, while further improving women's position, may have unintended consequences on men and marriage in general that deserve a closer look. Secondly, it is worthwhile continuing with the same line of research and examine how the Law impacts certain more narrowly defined groups of the population (for example, religious and ethnic groups), as well as consider whether the effects of the Law were permanent or transitory, or the more recent economic events (the recession, U.S.led sanctions) have reduced or even annulled such positive changes.

\section{Aknowledgements:}

We thank the Russia Longitudinal Monitoring survey (RLMS-HSE) for access to the data. RLMS-HSE is conducted by the National Research University Higher School of Economics and 'Demoscope' together with Carolina Population Center, the University of North Carolina at Chapel Hill and the Institute of Sociology RAS.

I would also like to thank the seminar participants of UNC-Greensboro (David Ribar and Dora Gicheva), discussants of the International Atlantic Economic and Eastern Economic conferences (USA), and an anonymous reviewer for constructive feedback.

\section{References}

Alderman H., Haddad P., Hoddinott J., Kanbur R. (1995) Unitary versus Collective Models of the Household: Is It Time to Shift the Burden of Proof? The World Bank Research Observer, 10 (1): 1-19.

Attanasio O., Lechene V. (2002). Tests of Income Pooling in Household Decisions. Review of Economic Dynamics, 5 (4): 720-748.

Blundell R., Chiappori P., Magnac T., Meghir C. (2007) Collective Labor Supply: Heterogeneity and Non-participation. Review of Economic Studies, (74): 417-445.

Brainard E. (2016) The Lasting Effect of Sex Ratio Imbalance on Marriage and Family: Evidence from World War II in Russia. Discussion paper 10130, IZA: Institute for the Study of Labor. 
Brainerd E. (1998) Winners and Losers in Russia's Economic Transition. The American Economic Review, 88 (5): 1094-1116.

Browning M., Bourguignon F., Chiappori P., Lechene V. (1994) Income and Outcomes: A Structural Model of Intrahousehold Allocation. Journal of Political Economy, 102 (6): 1067-1096.

Browning M., Chiappori P., Lechene V. (2004) Collective and Unitary Models: A Clarification. Working paper 15, University of Copenhagen - Institute of Economics.

Doss C. (1996) Testing among Models of Intrahousehold Resource Allocation. World Development, 24 (10): 1597-1609.

Elizarov V. (2012) Fertility Stimulus Measures and Support of Families with Children in Contemporary Russia. Demoscope Weekly, (495) (Jan 23- Feb 5).

Goldin C. (2006) The Quiet Revolution That Transformed Womens Employment, Education and Family. American Economic Review Papers and Proceedings, 96 (2): 1-21.

Haddad L., Hoddinott J. (1994) Women's Income and Boy-girl Anthropometric Status in the Cote d'Ivoire. World Development, 22 (4): 543-553.

Kalugina E., Sofer C., Radtchenko N. (2009) Intra-household Inequailty in Transitional Russia. Review of Economics of the Household, (7): 447-471.

Lacroix G., Radtchenko N. (2011) The Changing Intra-household Resource Allocation in Russia. Journal of Population Economics, (24): 85-106.

Lundberg S., Pollak R. (1996) Bargaining and Dsitribution in Marriage. The Journal of Economic Perspectives, 10 (4): 139-158.

Lundberg S., Pollak R., Wales T. (1997) Do Husbands and Wives Pool Their Resources. The Journal of Human Resources, 32 (3): 463-480.

Maitra P. (2004) Parental Bargaining, Health Inputs and Child Mortality in India. Journal of Health Economics, 23 (2): 259-291.

Manser M., Brown M. (1980) Marriage and Household Decision-Making: A Bargaining Analysis. International Economic Review, 21 (1): 31-44.

McElroy M., Horney M. (1981) Nash-Bargained Household Decisions: Toward a Generalization of the Theory of Demand. International Economic Review, 22 (2): 333-349.

Quisumbing A., Mallucio J. (2000) Intrahousehold Allocation and Gender Relations: New Empirical Evidence from Four Developing Countries. Fend discussion paper 84, International Food Policy Research Institute.

RLMS-HSE (1992-2012) Russia Longitudinal Monitoring Survey-Higher School of Economics. Available at: www.cpc.unc.edu/projects/rlms-hse (accessed 21 May 2018).

Rubaclava L., Thomas D. (2000) Family Bargaining and Welfare. Papers 00-10, RAND. Available at: https://ipl.econ.duke.edu/dthomas/docs/ppr/famwelf.pdf (accessed 21 May 2018).

Schultz P. (1990) Testing the Neoclassical Model of Family Labor Supply and Fertility. Journal of Human Resources, 25 (4): 599-634.

Selezneva E. (2010) What Makes Russian Women (un)happy? A Closer Look at the Family. Working paper 287, Osteuropa-Institute Regensburg.

Slonimczyk F., Yurko A. (2013) Assessing the Impact of the Maternity Capital Policy in Russia Using a Dynamic Model of Fertility and Employment. Discussion paper 7705, IZA. Available at: http://ftp.iza.org/dp7705.pdf (accessed 21 May 2018).

Thomas D. (1990) Intra-Household Resource Allocation: An Inferential Approach. The Journal of Human Resources, 25 (4): 635-664.

Thomas D., Contreras D., Frankenberg E. (1999) Distribution of power within the household and child health. Indonesian Family Life Survey. Working paper, IFLS. Available at https://pdfs.semanticscholar.org/6eda/e003132888da9db988584ab0ad2cbeb33693.pdf (accessed 21 May 2018). U. S. Bureau of Labor Statistics (2013) Women in the Labor Force: A Databook. Report 1040. Available: https://www.bls.gov/cps/wlf-databook-2012.pdf (accessed 21 May 2018). 